\title{
PULL AND BENDING FORCE USING FIBERGLASS WR EPOXY COMPOSITE MATERIALS AND FIBER CARBON EPOXY
}

\author{
Alphario Rachmatino Yudiana \\ Jurusan Teknik Dirgantara-Sekolah Tinggi Teknologi Adisutjipto \\ alphario95@gmail.com
}

\begin{abstract}
Bending testing is carried out in the lab. Nurtanio Adisutjipto College of Technology Yogyakarta uses the Gotech Testing Machine INC (Universal Testing Machine) UTM testing machine where the results obtained in the test are in the form of a graphic in which the maximum load value, elastic modulus, area, yield point and span have been obtained. From the results of these tests, we can compare the average value of the maximum load and the modulus of elasticity received in each specimen with variations in carbon fiber and WR fiberglass.
\end{abstract}

Keyword : INC, Fiber, bending and UTM

\section{Latar Belakang}

Pesawat tanpa awak PUNA (Pesawat Udara Nir Awak) adalah jenis pesawat terbang yang dikendalikan alat sistem kendali jarak jauh lewat gelombang radio. Pada dasarnya PUNA adalah pesawat yang dapat dikendalikan jarak jauh untuk menjalankan misi tertentu. Dewasa ini penggunaan dari PUNA diaplikasikan pada berbagai bidang. Pentingnya pemilihan material yang digunakan sebagai bahan pembuatan pesawat tanpa awak PUNA itu sendiri menjadi sangat penting [1][2][3][4]Penelitian ini dilakukan untuk membuat dan menganalisis kekuatan dari material yang akan digunakan sebagai bahan pembuatan PUNA dengan menggunakan bahan material komposit. Bahan komposit yang akan diteliti adalah campuran resin epoxy dengan fiberglass WR (Wofen Roving) dan resin epoxy dengan fiber carbon. Melalui penelitian ini diharapkan didapatkan suatu bahan komposit yang ringan dan memiliki sifat mekanik (mechanical properties) yang bai[5][6][7].Dengan adanya pengembangan dari PUNA itu sendiri, maka diharapkan pengembangan dari sisi material harus lebih ringan namun kuat untuk bagian seperti badan dan sayap pesawat itu sendiri. Sehingga dalam penelitian ini penulis akan melakukan pengujian spesimen pada material komposit fiberglass WR epoxy dan fiber carbon epoxy yang bertujuan untuk mengetahui kekuatan dari hasil material yang akan dibuat $[7][8][9][10]$

\section{Metodologi Penelitian}

PUNA 5774-Trainer adalah jenis pesawat fixed wing dengan misi untuk pelatihan pilot PUNA sebelum pada akhirnya dapat menerbangkan pesawat PUNA yang sebenarnya. PUNA 5774-Trainer [11]. Dalam penelitian ini menggunakan beberapa metode penelitian antara lain metode obsevasi, literature dari berbagai riset sebelumnya. Berikut alur penelitian dalam dalam penelitian ini adalah

a. Pengumpulan Data dan Studi Literatur

Pengumpulan data dan studi literatur dilakukan dengan membaca penelitian sebelumnya, jurnal dan buku literatur yang berhubungan dengan tema permasalahan yang akan dibahas. Adapun selain membaca juga menggunakan metode wawancaea, yaitu dengan mewawancarai orang yang memahami tentang hal yang akan diteliti. 
b. Penentuan Alat dan Bahan

Bertujuan untuk menyiapkan segala bentuk alat dan bahan yang akan digunakan dalam proses pembuatan spesimen.

c. Pengolahan Data dan Pembahasan

Pengolahan data yang telah didapatkan dari pengumpulan data kemudian diolah sesuai dengan rumusan masalah dan pembahasan.

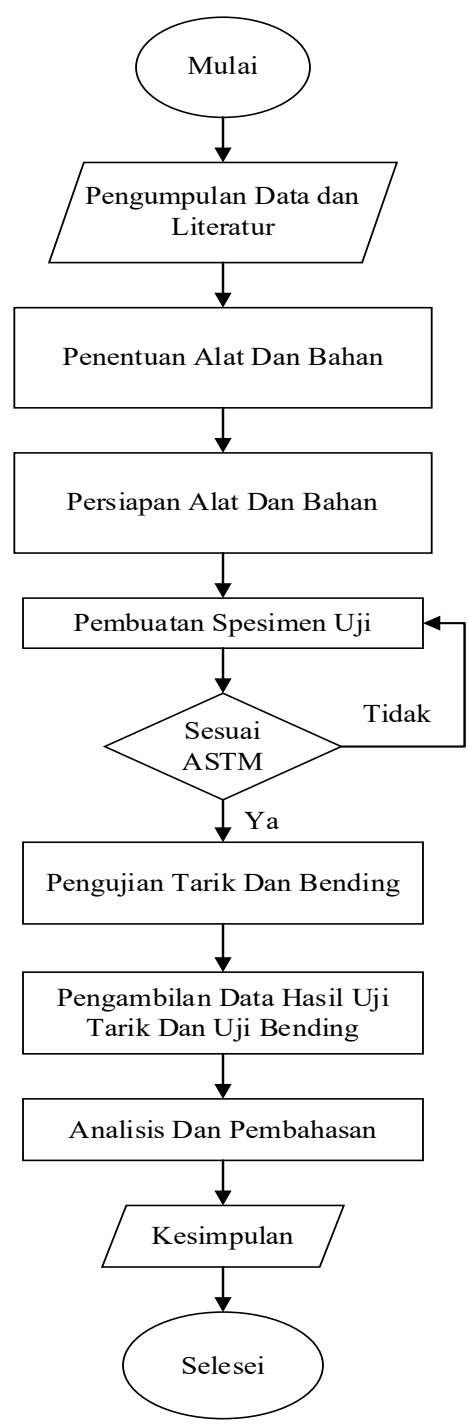

Gambar 1. Diagram alur penelitian

\section{Hasil dan Pembahasan}

Pengujian Tarik dilakukan di lab. Nurtanio Sekolah Tinggi Teknologi Adisutjipto Yogyakarta menggunakan mesin uji UTM (Universal Testing Machine) merk Gotech Testing Machine INC dimana hasil yang didapat pada penujian berupa grafik yang di dalamnya sudah didapatkan nilai beban maksimum, modulus elastisitas, area, yield point dan yield strength. Dari hasil pengujian tersebut, kita dapat membandingan nilai rata-rata beban maksimum dan modulus elastis yang diterima pada setiap specimen dengan variasi bahan fiber carbon dan fiberglass wr. 


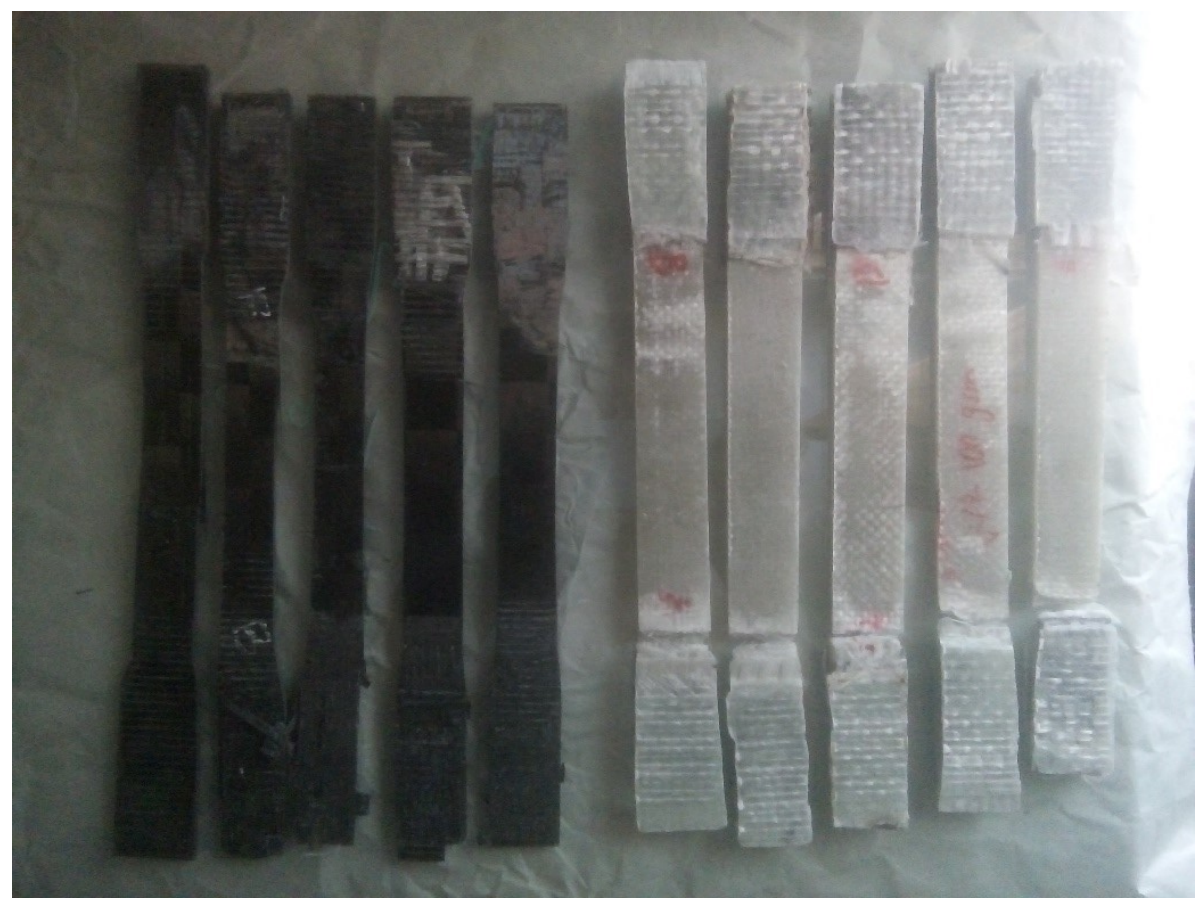

Gambar 2. Hasil Pengujian Tarik Fiber carbon Dan Fiberglass WR

Tabel 1. Hasil Patahan Spesimen Uji Tarik Fiber Carbon Epoxy

\begin{tabular}{|c|c|c|c|c|}
\hline Spesimen & Kode & Tipe Patahan & Area Patahan & Lokasi \\
\hline A & DGM & Edge Delamination & Gage & Middle \\
\hline B & DGM & Edge Delamination & Gage & Middle \\
\hline C & DGM & Edge Delamination & Gage & Middle \\
\hline D & DGM & Edge Delamination & Gage & Middle \\
\hline E & DGM & Edge Delamination & Gage & Middle \\
\hline
\end{tabular}

Berdasarkan kode kegagalan uji Tarik dalam ASTM D3090 spesimen A, B, C, D, dan E mengalami bentuk patahan sesuai kode DGM dengan tipe patahan (failure type) edge delamination, area patahan (failure type) gage, lokasi patahan (failure location) middle.

Tabel 2. Hasil Pengujian Spesimen Uji Tarik Fiberglass WR

\begin{tabular}{|c|c|c|c|c|}
\hline Spesimen & Kode & Tipe Patahan & Area Patahan & Lokasi \\
\hline A & LAT & Lateral & At Grip & Top \\
\hline B & LAT & Lateral & At Grip & Top \\
\hline C & LAT & Lateral & At Grip & Top \\
\hline D & LAT & Lateral & At Grip & Top \\
\hline E & LAT & Lateral & At Grip & Top \\
\hline
\end{tabular}


Berdasarkan kode kegagalan uji Tarik dalam ASTM D3090 spesimen A, B, C, D, dan E mengalami bentuk patahan sesuai kode LAT dengan tipe patahan (failure type) lateral, area patahan (failure type) at grip, lokasi patahan (failure location) top. Adapun data dari hasil pada saat pengujian tarik komposit untuk bahan fiber carbon dan fiberglass wr adalah sebagai berikut:

Tabel 3. Hasil Pengujian Tarik Fiber Carbon Epoxy

\begin{tabular}{|c|c|c|c|c|c|c|c|}
\hline \multirow{2}{*}{ Spesimen } & \multicolumn{2}{|c|}{ Max Load } & \multirow{2}{*}{ Area } & \multicolumn{2}{c|}{ Elastic Modulus } & $\begin{array}{c}\text { Yield } \\
\text { Point }\end{array}$ & $\begin{array}{c}\text { Yield } \\
\text { Strength }\end{array}$ \\
\cline { 2 - 8 } & $\mathbf{K g f}$ & $\mathbf{N}$ & $\mathbf{M m}$ & $\mathbf{k g f} / \mathbf{m m}^{\mathbf{2}}$ & $\mathbf{M P a}$ & $\mathbf{k g f} / \mathbf{m m}^{\mathbf{2}}$ & $\mathbf{\text { kgf/mm }}$ \\
\hline A & $3.240,690$ & $31.780,31$ & 42,5 & 61,57 & 603,7954 & 1026,018 & 74,237 \\
\hline B & $3.795,3$ & $37.219,18$ & 44,2 & 75,092 & 736,401 & 1081,074 & 76,706 \\
\hline C & $2.019,045$ & $19.800,07$ & 44,2 & 63,706 & 624,7424 & 1291,455 & 57,262 \\
\hline D & $3.961,592$ & $38.849,95$ & 42,5 & 74,161 & 727,271 & 1470,952 & 65,494 \\
\hline E & $4.725,408$ & $46.340,42$ & 44,2 & 96,384 & 945,2042 & 1544,441 & 99,487 \\
\hline rata-rata & $3.548,407$ & $34.797,99$ & 43,520 & 74,18 & 727,483 & $1.282,79$ & 74,637 \\
\hline
\end{tabular}

Berdasarkan hasil uji tarik pada spesimen fiber carbon epoxy dengan menyesuaikan ukuran dalam ASTM D3090 didapatkan nilai rata-rata pada spesimen A, B, C, D, dan E dengan nilai max load 34.797,99 N, elastic modulus $727,483 \mathrm{MPa}$, dan yield strength 74,637 kgf $/ \mathrm{mm}^{2}$.

Tabel 4. Hasil Pengujian Tarik Fiberglass WR Epoxy

\begin{tabular}{|c|c|c|c|c|c|c|c|}
\hline \multirow{2}{*}{ Spesimen } & \multicolumn{2}{|c|}{ Max Load } & \multirow{2}{*}{ Area } & \multicolumn{2}{c|}{ Elastic Modulus } & $\begin{array}{c}\text { Yield } \\
\text { Point }\end{array}$ & $\begin{array}{c}\text { Yield } \\
\text { Strength }\end{array}$ \\
\cline { 2 - 8 } & $\mathbf{K g f}$ & $\mathbf{N}$ & $\mathbf{M m}$ & $\mathbf{k g f} / \mathbf{m m}^{\mathbf{2}}$ & $\mathbf{M P a}$ & $\mathbf{k g f} / \mathbf{m m}^{\mathbf{2}}$ & $\mathbf{k g f} / \mathbf{m m}^{\mathbf{2}}$ \\
\hline A & $1.552,560$ & $15.225,41$ & 62,5 & 22,211 & 217,8155 & 568,576 & 23,384 \\
\hline B & $1.201,732$ & $11.784,97$ & 62,5 & 17,679 & 173,3718 & 475,297 & 17,332 \\
\hline C & $1.213,118$ & $11.896,62$ & 62,5 & 17,112 & 167,8114 & 484,27 & 18,602 \\
\hline D & $1.656,271$ & $16.242,47$ & 62,5 & 23,391 & 229,3874 & 634,679 & 24,479 \\
\hline E & $1.295,357$ & $12.703,11$ & 62,5 & 19,222 & 188,5034 & 509,452 & 18,577 \\
\hline rata-rata & $1.383,808$ & $13.570,52$ & 62,500 & 19,92 & 195,378 & 534,45 & 20,475 \\
\hline
\end{tabular}

Berdasarkan hasil uji tarik pada spesimen fiberglass WR epoxy dengan menyesuaikan ukuran dalam ASTM D3090 didapatkan nilai rata-rata pada spesimen A, B, C, D, dan E dengan nilai max load 13.570,52 $\mathrm{N}$, elastic modulus 195,378 $\mathrm{MPa}$, dan yield strength 20,475 $\mathrm{kgf} / \mathrm{mm}^{2}$. Data yang sudah didapat akan dihitung kembali untuk mendapatkan nilai tegangan tarik dan regangan pada komposit fiber carbon dan fiberglass wr. Berikut adalah contoh perhitungan untuk mencari nilai tegangan tarik dan regangan pada specimen D komposit fiberglass wr epoxy menggunakan persamaan 2.12:

Diketahui:
$1=250 \mathrm{~mm}$
(Panjang Spesimen)
$\mathrm{W}=25 \mathrm{~mm}$
(Lebar Spesimen)
$\mathrm{t}=2,5 \mathrm{~mm}$
(Tebal Spesimen)
$\mathrm{P}=1.656,271 \mathrm{kgf} \quad$ (Max Load Spesimen)
$\mathrm{E}=23,391 \mathrm{kgf} / \mathrm{mm} 2 \quad$ (Elastic Modulus Spesimen) 
$\sigma_{i}=\frac{P_{i}}{A}$

$\sigma_{i}=\frac{1.656,271 \mathrm{kgf}}{62,5 \mathrm{~mm}}$

$\sigma_{i}=26,500 \mathrm{kgf} / \mathrm{mm}^{2}$

$\sigma_{i}=259,880 \mathrm{MPa}$

Pada hasil pengujian didapatkan nilai dari modulus elastisitas, maka untuk menghitung nilai regangan menggunakan ASTM D3039

$\Delta_{\in}=\frac{\Delta_{\sigma}}{E^{\text {chord }}}$

$\Delta_{\epsilon}=\frac{26,500 \mathrm{kgf} / \mathrm{mm}^{2}}{23,391 \mathrm{kgf} / \mathrm{mm}^{2}}$

$\Delta_{\epsilon}=1,133$

$E^{\text {chord }}=\frac{\Delta_{\sigma}}{\Delta_{\epsilon}}$

$E^{\text {chord }}=\frac{26,500}{1,133}$

$E^{\text {chord }}=23,289 \mathrm{kgf} / \mathrm{mm}^{2}$

Sehingga selisih dari nilai antara perhitungan modulus elastisitas secara manual dan dari hasil pengujian adalah $0,005 \mathrm{kgf} / \mathrm{mm}^{2}$.

Tabel 5. Nilai Tegangan Dan Regangan Uji Tarik Fiber Carbon Epoxy

\begin{tabular}{|c|c|c|c|c|c|}
\hline \multirow{2}{*}{ Spesimen } & \multicolumn{2}{|c|}{ Tegangan Tarik } & \multicolumn{2}{c|}{ Elastic Modulus } & \multirow{2}{*}{ Regangan } \\
\cline { 2 - 5 } & $\mathbf{k g f} / \mathbf{m m}^{\mathbf{2}}$ & $\mathbf{M P a}$ & $\mathbf{K g f} / \mathbf{m m}^{\mathbf{2}}$ & $\mathbf{M P a}$ & \\
\hline A & 51,851 & 508,485 & 61,57 & 603,7954405 & 0,842 \\
\hline B & 60,725 & 595,507 & 75,092 & 736,4009618 & 0,809 \\
\hline C & 32,305 & 316,801 & 63,706 & 624,7424449 & 0,507 \\
\hline D & 63,385 & 621,599 & 74,161 & 727,2709707 & 0,855 \\
\hline E & 75,607 & 741,447 & 96,384 & 945,2041536 & 0,784 \\
\hline Rata-rata & 56,775 & 556,768 & 74,183 & 727,483 & 0,759 \\
\hline
\end{tabular}

Berdasarkan hasil perhitungan pada spesimen fiber carbon epoxy dengan menyesuaikan perhitungan dalam ASTM D3090 didapatkan nilai rata-rata pada spesimen A, B, C, D, dan E dengan nilai tegangan tarik 556,768 $\mathrm{MPa}$, elastic modulus $727,483 \mathrm{MPa}$, dan regangan 0,759 .

Tabel 6. Nilai Tegangan Dan Regangan Uji Tarik Fiberglass WR Epoxy

\begin{tabular}{|c|c|c|c|c|c|}
\hline \multirow{2}{*}{ Spesimen } & \multicolumn{2}{|c|}{ Tegangan Tarik } & \multicolumn{2}{c|}{ Elastic Modulus } & \multirow{2}{*}{ Regangan } \\
\cline { 2 - 5 } & $\mathbf{k g f} / \mathbf{m m}^{\mathbf{2}}$ & $\mathbf{M P a}$ & $\mathbf{K g f} / \mathbf{m m}^{\mathbf{2}}$ & $\mathbf{M P a}$ & \\
\hline A & 24,841 & 243,607 & 22,211 & 217,8155032 & 1,118 \\
\hline B & 19,228 & 188,559 & 17,679 & 173,3717654 & 1,088 \\
\hline C & 19,410 & 190,346 & 17,112 & 167,8113948 & 1,134 \\
\hline D & 26,500 & 259,880 & 23,391 & 229,3873502 & 1,133 \\
\hline E & 20,726 & 203,250 & 19,222 & 188,5034263 & 1,078 \\
\hline Rata-rata & 22,141 & 217,128 & 19,923 & 195,378 & 1,110 \\
\hline
\end{tabular}


Berdasarkan hasil perhitungan pada spesimen fiberglass WR epoxy dengan menyesuaikan perhitungan dalam ASTM D3090 didapatkan nilai rata-rata pada spesimen A, B, C, D, dan E dengan nilai tegangan tarik 217,128 MPa, elastic modulus 195,378 MPa, dan regangan 1,110 .

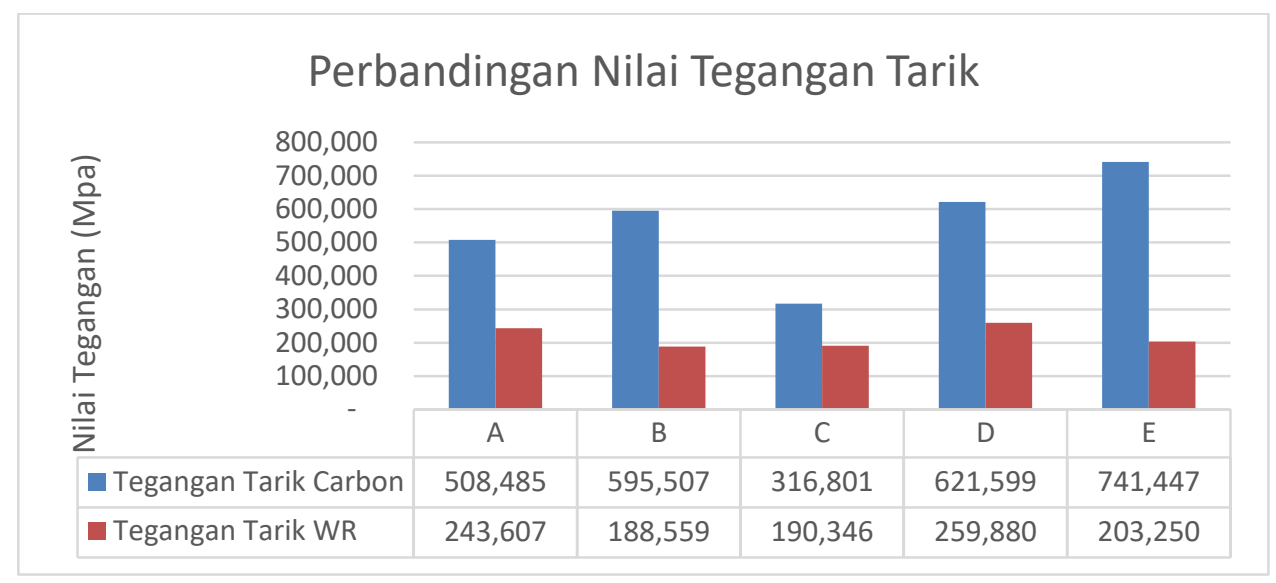

Gambar 3. Grafik Perbandingan Nilai Tegangan Komposit Uji Tarik

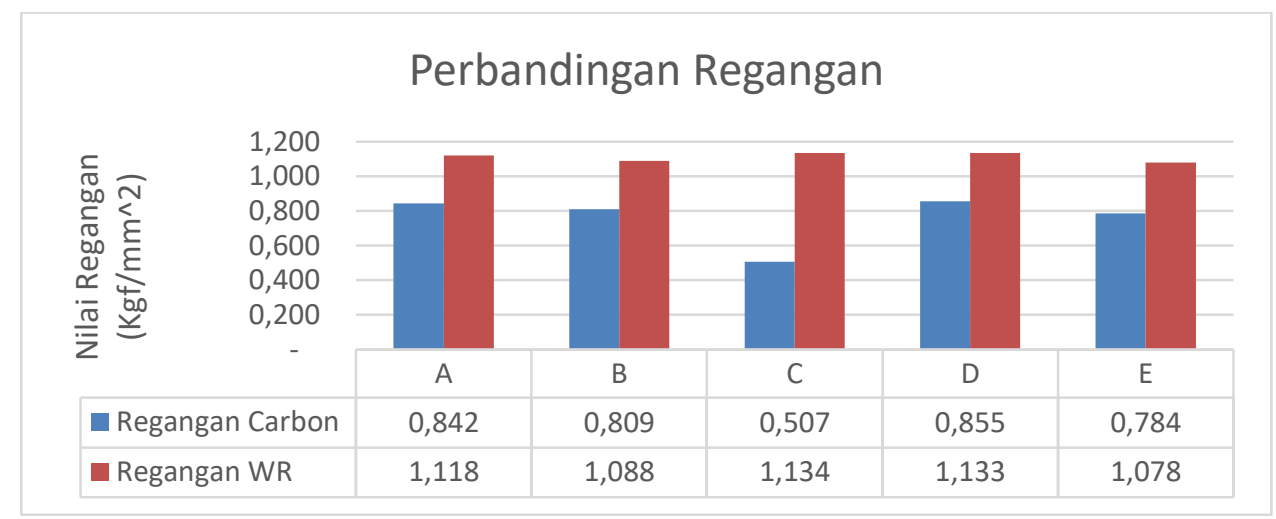

Gambar 4. Grafik Perbandingan Nilai Regangan

Pada Gambar Grafik Perbandingan Nilai Regangan dapat dilihat bahwa nilai regangan komposit fiberglass WR lebih besar dibandingkan nilai fiber carbon dengan nilai tertinggi di specimen C pada komposit fiberglass wr sebesar 1,134. 


\section{Perbandingan Elastic Modulus}

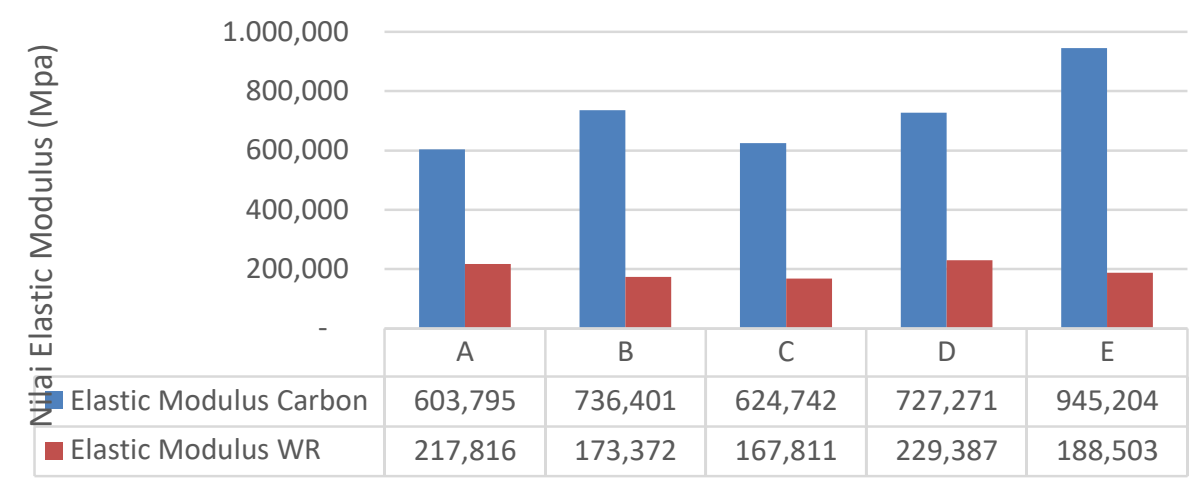

Gambar 5. Grafik Perbandingan Nilai Elastic Modulus

Sama seperti nilai tegangan, nilai elastic modulus terbesar adalah pada fiber carbon. Ini dapat dilihat dari Gambar 4.10 Grafik Perbandingan Nilai Elastic Modulus, dimana pada hasil grafik tersebut nilai elastic modulus komposit fiber carbon sebesar 736,401 MPa.

Tabel 7. Hasil Pengujian Bending Fiber Carbon Epoxy

\begin{tabular}{|c|c|c|c|c|c|c|c|}
\hline \multirow{2}{*}{ Spesimen } & \multicolumn{2}{|c|}{ Max Load } & Area & \multicolumn{2}{|c|}{ Elastic Modulus } & Yield Point & Span \\
\cline { 2 - 8 } & $\mathbf{K g f}$ & $\mathbf{N}$ & $\mathbf{m m}$ & $\mathbf{k g f} / \mathbf{m m}^{\mathbf{2}}$ & $\mathbf{M P a}$ & $\mathbf{k g f} / \mathbf{m m}^{\mathbf{2}}$ & $\mathbf{~ m m}^{\mathbf{2}}$ \\
\hline A & 51,469 & 504,74 & 52 & 0,856 & 8,394492 & 15,104 & 128 \\
\hline B & 68,73 & 674,01 & 52 & 1,064 & 10,43428 & 14,979 & 128 \\
\hline C & 67,904 & 665,91 & 52 & 1,061 & 10,40486 & 15,185 & 128 \\
\hline D & 73,005 & 715,93 & 52 & 1,137 & 11,15016 & 15,748 & 128 \\
\hline E & 62,157 & 609,55 & 52 & 0,991 & 9,71839 & 15,307 & 128 \\
\hline Rata-rata & 64,653 & 634,03 & 52,000 & 1,02 & 10,020 & 15,26 & 128,000 \\
\hline
\end{tabular}

Berdasarkan hasil pengujian pada specimen bending fiber carbon epoxy dengan menyesuaikan perhitungan dalam ASTM D7264 didapatkan nilai rata-rata pada spesimen A, $\mathrm{B}, \mathrm{C}, \mathrm{D}$, dan E dengan nilai tegangan tarik $634,03 \mathrm{~N}$, dan elastic modulus 10,020 MPa.

Tabel 8. Hasil Pengujian Bending Fiberglass WR Epoxy

\begin{tabular}{|c|c|c|c|c|c|c|c|}
\hline \multirow{2}{*}{ Spesimen } & \multicolumn{2}{|c|}{ Max Load } & Area & \multicolumn{2}{|c|}{ Elastic Modulus } & Yield Point & Span \\
\cline { 2 - 8 } & $\mathbf{K g f}$ & $\mathbf{N}$ & $\mathbf{m m}$ & $\mathbf{k g f} / \mathbf{m m}^{\mathbf{2}}$ & $\mathbf{M P a}$ & $\mathbf{k g f} / \mathbf{m m}^{\mathbf{2}}$ & $\mathbf{m m}^{\mathbf{2}}$ \\
\hline $\mathrm{A}$ & 28,210 & 276,65 & 52 & 0,403 & 3,95208 & 5,2 & 128 \\
\hline B & 32,152 & 315,30 & 52 & 0,468 & 4,589512 & 5,657 & 128 \\
\hline C & 27,591 & 270,58 & 52 & 0,392 & 3,844207 & 4,307 & 128 \\
\hline D & 33,152 & 325,11 & 52 & 0,483 & 4,736612 & 6,526 & 128 \\
\hline E & 31,477 & 308,68 & 52 & 0,455 & 4,462026 & 5,708 & 128 \\
\hline Rata-rata & 30,516 & 299,26 & 52,000 & 0,44 & 4,317 & 5,48 & 128 \\
\hline
\end{tabular}


Berdasarkan hasil pengujian pada specimen bending fiberglass WR epoxy dengan menyesuaikan perhitungan dalam ASTM D7264 didapatkan nilai rata-rata pada spesimen A, B, C, D, dan E dengan nilai tegangan tarik 299,26 N, dan elastic modulus 4,317 $\mathrm{MPa}$.Berdasarkan data hasil perhitungan diatas dapat diketahui nilai rata-rata tegangan bending pada komposit fiberglass WR epoxy memiliki nilai tegangan bending sebesar 276,243 MPa.

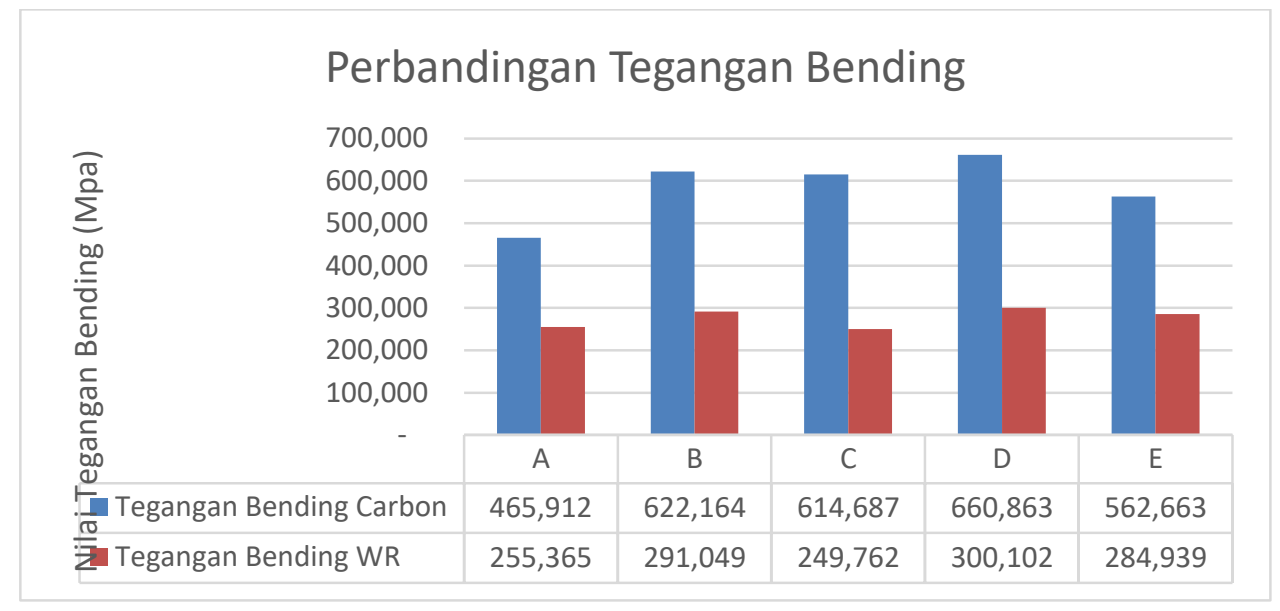

Gambar 6. Grafik Nilai Perbandingan Nilai Tegangan Uji Bending

Sesuai hasil perhitungan yang kemudian dilakukan perbandingan menggunakan grafik seperti pada Gambar 4.12 Grafik Nilai Perbandingan Nilai Tegangan Uji Bending diketahui bahwa komposit fiber carbon memiliki tegangan bending yang lebih tinggi dibandingkan dengan komposit fiberglass WR.

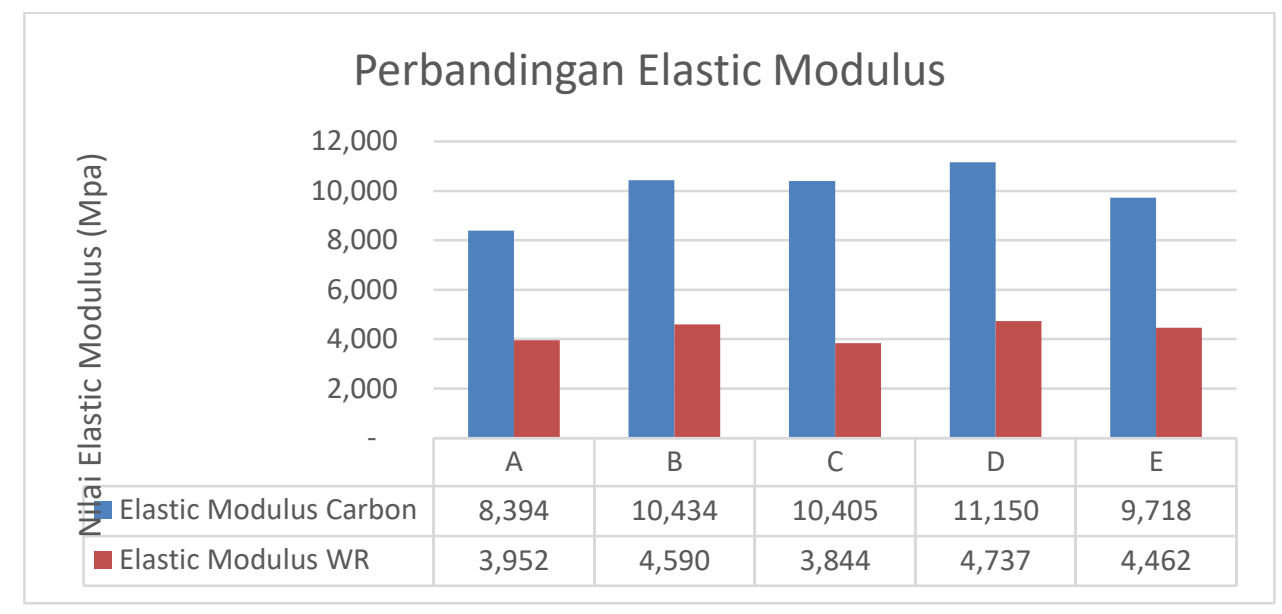

Gambar 1. Grafik Nilai Perbandingan Nilai Elastic Modulus Uji Bending

\section{Kesimpulan}

Berdasarkan data hasil pengujian dan perhitungan uji tarik dapat diketahui nilai rata-rata tegangan pada komposit fiber carbon epoxy mempunyai nilai rata-rata yaitu 556,768 $\mathrm{MPa}$, dengan nilai rata-rata regangan yaitu 0,759 , dan nilai modulus elastisitas rata-rata yaitu 727,483 MPa. Sedangkan untuk material komposit fiberglass WR epoxy mempunyai nilai rata-rata yaitu $217,128 \mathrm{MPa}$, dengan nilai rata-rata regangan yaitu 1,110 , dan nilai modulus elastisitas rata-rata yaitu 195,378 MPa.Untuk hasil pengujian dan perhitungan uji bending dapat 
diketahui nilai rata-rata maximum load pada komposit fiber carbon epoxy mempunyai nilai rata-rata yaitu $634,03 \mathrm{~N}$, dengan nilai rata-rata tegangan yaitu $585,257 \mathrm{MPa}$, dan nilai modulus elastisitas rata-rata yaitu 10,020 MPa. Sedangkan untuk material komposit fiberglass WR epoxy mempunyai nilai maximum load rata-rata yaitu 299,26 MPa, dengan nilai rata-rata tegangan yaitu 276,243 $\mathrm{MPa}$, dan nilai modulus elastisitas rata-rata yaitu $128,00 \mathrm{MPa}$

\section{Daftar Pustaka}

[1] ASTM D3039 Standard Test Method For Tensile Properties Of Polymer Matrix Composite Materials.

[2] ASTM D7264 Standard Test Method For Flexural Properties Of Polymer Matrix Composite Materials.

[3] Andy Lennon, 2002, R/C Model Aircraft Design Practical Techniques For Building Better Models, United State Of America.

[4] Groover, Mikell. P, Fundamentals Of Modern Manufacturing: Materials, Processes And System, $3^{\text {rd }}$ Edition, United States Of America.

[5] [Daniel P. Raymer, Aicraft Design: A Conceptual Approach, American Institute Of Aeronautics, Inc., 370 L'enfant Promenade, S.W., Washington, D.C.

[6] Jay Gundlach, Deigning Unmanned Aircraft Systems: A Comprehensive Approach, Aurora Flight Sciences, Manassas Virginia.

[7] Wisnu Wardana, 2018, Proses Manufaktur Pada Pesawat UAV V-Sky 14, Sekolah Tinggi Teknologi Adisutjipto, D.I. Yogyakarta.

[8] Burhanudin Rohani, 2016, Proses Produksi Prototipe Pesawat Platform Unmanned Aerial Vehicle (UAV) Sky King, Sekolah Tinggi Teknologi Adisutjipto, D.I. Yogyakarta.

[9] Brillian Indra Wibowo, 2019, Analisis Proses Penggabungan Komposit Menggunakan Adhesive Bonding Beserta Kekuatannya Terhadap Uji Tarik, Sekolah Tinggi Teknologi Adisutjipto, D.I.Yogyakarta.

[10] Arifin Mulia, 2016, Rancang Bangun Dan Analisa System Kendali Pid Pada Unmanned Aerial Vehicle (UAV) Fixed Wing, Jurusan Teknik Mesin, Fakultas Teknologi Industri, Institut Teknologi Sepuluh Nopember, Surabaya.

[11] Juliono S, Ikhwansyah I, Syahrul A, M. Sabri, Tugiman, Mahadi, 2016, Pembuatan Dan Analisis Gaya Badan Pesawat Tanpa Awak Dari Bahan Material Komposit Yang Diperkuat Polyester Dan Serat Rock Wool Dengan Metode Hand Lay Up, Departemen Teknik Mesin, Fakultas Teknik, Universitas Sumatera Utara, Sumatera Utara 